\title{
Morphology and Molecular Characterization of Four Types of Ramies (Boehmeria nivea (L.) Gaud) Collection Experimental Farm Faculty of Agriculture Andalas University
}

\author{
Denny Yulfa ${ }^{1}$, Reni Mayerni ${ }^{2}$, Yusniwati ${ }^{2}$
}

${ }^{1}$ Department of Agronomy, Andalas University, Indonesia
${ }^{2}$ Department of Agrotechnology, Andalas University, Indonesia

\begin{abstract}
The purpose of this study was to collect and determine the morphological and molecular character of the ramies in West Sumatra. This study was conducted in May-October 2018 Experimental Farm, Faculty of Agriculture, University of Andalas Padang. This activity also used the clone Padang 3 and Ramindo 1 as a comparison. The results of this study indicated that the ramie plant could grow to a height of 1058 meters above sea level to the point where the coordinates $0^{\circ} 15^{\prime} 30^{\prime \prime S o u t h}$ Latitude and $100^{\circ} 15^{\prime} 45^{\prime \prime}$ east longitude. Ramie highest Situjuah accession $150.03 \mathrm{~cm}$ and the lowest at $91.7 \mathrm{~cm}$ Matur accession. The longest and widest leaf observations contained in the accession Situjuah while the shortest and smallest obtained at Matur accession. On accession Situjuah, Matur, and clones Ramindo 1 had male and female flowers but clone Padang 3 only had female flowers. Harvesting fastest in clones Ramindo 1 was 123 days and the longest in clones Padang 3 was 133 days. The numbers of banding pattern resulting from PCR amplification were 74 tapes (68 a polymorphic bands while the rest was the number of monomorphic bands).
\end{abstract}

Keywords-Morphology, Molecular, characterization, Boehmeria nivea.

\section{INTRODUCTION}

Indonesia is an agricultural country which has a quite extensive forest area with the greatest biodiversity primarily on the varieties of plants, with the number of the existing plant that is equal to 55\%, Indonesia occupied the top five in the world (Amin et al., 2014). The varieties of plants give several benefits for humansuch as foodstuffs, building materials, traditional ceremonies, industrial materials of drugs and materials of textile.

Along with development of the textile industry in Indonesia, the need for raw materials of cotton fiber also continued to increase. However, to fulfill the needs of these raw materials, Indonesia has to import cotton fiber annually. According to the Directorate General of Estate Crops (2017), in 2013 Indonesia imported cotton fiber amounted to 676.682 ton with a value of US\$ 1.3 million, while in 2014 an increase in imports amounted to 711.747 ton of cotton fiber with a value of US\$ 1.4 million.

One of the efforts to overcome the dependence on raw materials of the textile industry is by using other natural fibers. Natural fibers that have the potential to be used as raw materials in the Indonesian textile industry is the ramie (Boehmeria nivea (L.) Gaud). This is because the ramie's has the characteristics and quality of high fiber (Angelini and Tavarini, 2013).

Ramie's (Boehmeria nivea (L.) Gaud.) is a perennial plant that has many benefits. This plant is known for fiber from the bark is used as a raw material in the textile industry, raw material pulp, paper, conservation of land (Mitra et al., 2013), compost, animal feed, roots are used as traditional medicine (Huang et al., 2015), and various other industrial products.

Productivity of ramie depends on fiber height and diameter, thick-thin bark and fiber yield. Ramie harvested for fiber production every 2 months so the first year can be 5-6 harvests (Liu et al., 2009).According to Sarkar et al. (2010),fibers of the ramies are two times more powerful than all plant-based fibers.

Ramie fiber also has another advantage such as the resistance to bacteria and a higher tensile strength under conditions of hygroscopic (Satya et al., 2013). According to Liu et al. (2015) ramie plant height is a major determining factor for the results of the fiber, because fiber ramie is extracted from the bark so that if the ramie is shorterthe fibers produced results also less. Even the results of Liu et al. (2014) the results of ramie fibers is largely determined by the number of stems per plant, fiber 
yield per plant, stem length, stem diameter, and thickness of the skin.

Meanwhile, Indonesia is very good country for the cultivation of ramie because according Suryanah et al. (2017) ramies are easy to grow in the tropics and will produce high when planted on the altitude 1310 meters above sea level. In West Sumatra, the variety of vegetation is still very high around the forest so that theunknown typeof ramie is still found. Knowledge of genetic diversity is very important in plant breeding activities to determine the pace of improvement in the quality, quantity and competitiveness of ramie fiber.

Based on the statement above, the conservation work with a ramie crop germplasm morphological observation and molecular characterization is done, which the result of conservation materials is used as comparison of two other clones of the ramies. Information on morphological characters is required to differentiate between plant accessions and probe distance or dissimilarity genetic kinship analysis so that it can be used as a base material improvement of the ramies. The farther the genetic distance elder in one species, the opportunity to produce new varieties are very large (Govindaraj et al., 2015). The purpose of this study is to collect and know the morphological and molecular character of the ramie's in West Sumatra.

\section{MATERIALS AND METHODS}

This research was conducted in May-October 2018 at Experimental Farm Faculty of Agriculture Andalas University. For morphology characterization were observed in the stems, leaves, flowers, and the production of ramie's. This morphological characterization refers to descriptor Mitra et al. (2013) and Aiguo (2018). While the molecular conducted DNA isolation, PCR amplification, and DNA electrophoresis. Primers used in the PCR amplification is OPF 04 OPF 05, OPH 07, OPX 02, and OPX 17.

The data collection was based on observation of morphological and molecular. The data were followed by analysis of phenotypic variability and similarity analysis using the Unweighted Pair Group Methods Aritmathic Average (UPGMA) version 2.02 at NTSYS software.

\section{RESULT}

\subsection{Exploration and Collection of Ramie}

The determination of two locations was based on the results of a preliminary survey in district. Based ontwo districts which have been designated as areas of research, there were 20 accessions of the ramies got. All ramies that had been explored, and then carried out ex situ conservation in the Experimental Farm Faculty of Agriculture,Andalas University, by means planted and characterized the important characteristics of it. The details of the ramie's accession number per district, sub district, coordinates and elevation can be seen in Table 1 .

\subsection{Morphology Characterization of Ramie}

Based on quantitative terms, the result of morphological observations on two accession and two clones of the ramies showed that there are any differences between population of the plant height, stem diameter, and number of tillers per hill. Qualitative characters showed different results which was found only in the parameters of the surface of the stem, while the stem color parameters for young and old trunks colors do not show different results. The results showed that the height of varieties of plant with the average at $150.03 \mathrm{~cm}$ Situjuah accession, acceding Matur is $91.7 \mathrm{~cm}$, Padang 3 as high as $108.03 \mathrm{~cm}$ Ramindo 1 is $129.72 \mathrm{~cm}$. Therefore, the highest ramiewasin Situjuah accession and for the lowest plant was contained in the accession Matur.

Based on the results of this research, it can be concluded thatthe largest trunk diameter obtained by accession Situjuah compared to other clones and the smallest trunk diameter obtained byaccession Matur. For Situjuah accession,the average of trunk diameter is 10.37 $\mathrm{mm}$ and the diameter of the rod accession to Matur is 6.05 $\mathrm{mm}$ then the average diameter of the rod clones Padang is 3 of $8.3 \mathrm{~mm}$ and a trunk diameter average at Ramindo 1 is 9, $08 \mathrm{~mm}$. Meanwhile, according to Yang et al. (2010) and Bene et al. (2011) ramie plant stems cylindrical stem diameter ranging from 11 to $38.5 \mathrm{~mm}$, but does not cover possible if the diameter of ramie only the range of 8 to 16 $\mathrm{mm}$ because it will depend on the environmental conditions of the plant growth.

The observations done on the parameters of the number of tillers per hill showed that the average chicks that appear on the accession Situjuah is 14.2 tillers and number of tillers on the accession Matur is 30.4, while the average number of tillers in Padang 3 clones is 9.8 tiller and tiller number in clones Ramindo 1 is 14 . From the explanation above, it can be concluded that the highest number of tillers obtained by accession Matur while the lowest number of tillers obtained by Padang 3 .

The variety of the height parameters plant, stem diameter, and number of tillers per hill and also the differences of stem surface, it is suspected that the plant is affected by inconstant environmental conditions during the research. According to Verdaguer et al. (2017), the factors affecting plant height beside the requirements of a place to grow and environmental conditions related to 
climate and weather in the cultivation area are genetic and nutrient. In accordance with the results of research and Angelini and Tavarini (2013), there was variation among plant height, stem diameter, and number of tillers per hill which is controlled by several or polygenic so strongly influenced by environmental conditions. Genetic factors will not show the character that brought exception with the environmental factors that meets the needs of a plant (Andrew et al., 2010). In connection with nutrients, Mitra et al. (2013) and Sharma et al. (2014) states the ramie is a plant which greedy of nutrients, because these plants have a rapid vegetative growth so that it can be harvested every two months.

Based on the observations of qualitative character on the surface of the rod, there are variations of accession on Matur, but not for Situjuah, Padang 3, and Ramindo 1. In general, the surface of the ramie's stem is hairy, but there are also ramie with thin hairy, rare, and thick. The surface of Matur and Padang 3 population is rarely hairy whereas the surface of steminSitujuah and Ramindo 1 is woolly. There is no differences between color parameter of yound and old ramies population The color of Young stem is green and the color of old stem is brown. The color differences between young and old stem can be seen in Figure 1.

In observation of leaf length showed that the average for the accession Situjuah is $18.15 \mathrm{~cm}$ and Matur is 12.47 $\mathrm{cm}$ meanwhile average lengthof leaves Padang 3 is 14.15 and Ramindo 1 is $12.92 \mathrm{~cm}$. From those data, we knowthat the longest leaf contained is Situjuah and the shortest is Matur. The growth of the ramie's leaf of accession Situjuah has an average $14.94 \mathrm{~cm}$ and Matur is $9.69 \mathrm{~cm}$, while Padang 3 is $12.01 \mathrm{~cm}$ and Ramindo 1is $11.5 \mathrm{~cm}$. For the average,the widest leaves contained in the accession Situjuah and for narrowestcontained in accession Matur. Based on data from the measurement of leaf length, it is obtained the result of the observations of leaf measure type, in Situjuah and Ramindo 1 is medium type while in Matur and Padang 3 is narrow type.

The average length of leaf petiole in Situjuah accession is $9.55 \mathrm{~cm}$ and Matur is 6.67 whereas in Padang 3 is $8.42 \mathrm{~cm}$ and the average length of petiole at Ramindo 1 is $7.33 \mathrm{~cm}$. Therefore, it was found the average length of the longest leaf petiole is Situjuah while the shortest petiole length contained is Matur (Figure 2).

This is consistent with Jose et al. (2017) that ramie leaves has a characteristic heart-shaped and smooth jagged edges, then the length of 7-20 cm, while width of $6-15 \mathrm{~cm}$. For the length of petiole, ranges from $3-12 \mathrm{~cm}$ long and even longer petioles also shorter than the length of the leaf, but everything depends on the clones.
According toLiu et al. (2014) derived from the ramie plant stem and wide leafy little usually produce puppies are not much different with the parent.

The observation on leaf shape, leaf edge shape, the shape of the tip of the leaf, the leaf base shape, and the shape of the leaf growth showed that there is no difference among the four ramies populations. On leaves hair on Situjuah, Matur, and Ramindo 1. Most ofpopulation is medium type, while in Padang 3, all populationis medium type.

Ramie leaf shaped like a heart wide, with a relatively large size compared to other similar leaves. Ramie leaves had short hair so it seems a bit rough, but it is relatively soft and not woody (Munawar et al., 2007; Hwang, 2010).Mitra et al.(2013) adds theramie leaf stems in the stem and located alternately, and downy leaf surface. Leaf photosynthetic active only at the top stem, the position of the leaf shoots growing near. The leaves are actively growing at the old plant occupies one-third of the top of the stem to the tip.

There is no different color of the petiole leaf in the population Situjuah, Matur, and Ramindo 1, that is reddish green color, while in Padang 3 clones is green. Furthermore, most of the color of the upper surface of the leaves also did not show any variation in Situjuah, Matur, and Ramindo 1, that is dark green,while for clones Padang 3,the all colors are dark green. There is also no different color betweenunder surface of the leaves and bone leaf, the colors are silvery white and green. Then the leaf color of Situjuah and Ramindo lis yellowish green but Matur is more dominant yellowish green and Padang 3 is green.

The according to Sharma et al. (2014) that the top surface of the leaf color is the dark green ramie and leaf color is silvery white underneath surface. Ramieleaf colored light green to dark green, depending on variety, age, care and cultivation systems.

Ramie flower is compound interest, every stick in one clump. The layout of the male flowers isunder stem segments while the female flowers are on the top of stem segments. Male flowers appear earlier than the female flowers. Observations obtained flowering date of average of Situjuah is 57.6 days,Matur 66 days, Padang 3 is 76.2 days and Ramindo 142.8 days. Therefore, the fastest flowering is Ramindo 1 and the longest is Padang 3. Speed flowering can also be controlled by genetic factors and environmental factors.

Gender flowers on each population Situjuah, Matur, and Ramindo 1 does not show the variety. In that population have sex male and female flowers on one plant, while Padang 3 has only female flowers in one 
plant. This is consistent with Mitra et al. (2013) which states that in certain clones and the female flowers are male flowers on one stem.

Male flower color in Situjuah, Matur, and Ramindo 1 did not show any variations, all of them only have green color. There are varieties of Character color of female flowers on the ramie's populations. For Situjuah is yellowish green,Matur is reddish, Padang 3 is green and Ramindo 1 is red.

Type of ramie flowering is different,there are many flowers in clone Situjuah and Ramindo while there is few flower in Matur and Padang 3. According to Mitra et al. (2013), a lot or little depending on that clones. It is also suspected nothing to do with the power of adaptation to altitude somewhere. The variety of the interest amount on each accession and clone ramie can be seen in Figure 3.

The fastest of harvesting namely is in clones Ramindo only 123 days than the longest harvesting in Padang 3 is 133 days. The period of harvest time affects the quality of the fibers from the ramies. Old or rapid harvest time can also be caused by altitude, soil fertility and plant growth conditions or factors of the seeds used (Mayerni, 2018).

Plant fresh weight showed that accession Situjuahis the heaviest fresh weight, thatis 632.48 grams then the lightest is in Padang 3, thatis 251.78 grams. Similar to the results of the fresh weight of the heaviest rod is Situjuah, thatis 372.46 grams and the lightest is Matur, with 181.11 grams. As for the weight of crude fiber in clones Ramindo 1 is a coarse fiber heaviest weight (43.83 grams) and for the lightest is Padang 3 (31.51 grams). Value of weights on the parameters of plant fresh weight, stem fresh weight, and the weight of crude ramies fiber is influenced by the number of tillers, plant height, stem diameter.

\subsection{Phenotypic Variability Analysis}

Based on the value of variability in Table 2, in comparison between the value and the character is seen that the value of the narrow variability does not have much difference between its value. As for the wide variability values show much difference between its value, so the phenotypic variance is less than twice the standard deviation.

Value variability in morphological characters can be influenced by genetic factors and environmental factors. Qualitative character can be controlled by simplegenic with little environmental impact. Environmental factors related to other factors that cause the appearance varies so that a plant has genetic diversity. For the quantitative character is influenced by polygenic and highly influenced by the environment around the plant (Andrew et al., 2010). Mulder et al. (2016) said that a population has a wide phenotypic variability is not necessarily wide genetic variability, due to genetic via phenotypic appearance is influenced by environmental factors.

\subsection{Similarity Analysis}

The results of dendogram based on qualitative character or the mixing of quantitative and qualitative character indicate that each variant of ramie found has a different kinship. The Dissimilarity was caused by the different morphological characters between the ramies, both quantitative and qualitative character. All qualitative characters and 2 quantitative characters (trunk diameter and length of the leaf petiole) showed similarities.

Based on dendogram in qualitative characters showed four relationship patterns of ramie's population which had an alliance with the kinship coefficient from 0.29 to 1.00 , or $29 \%-100 \%$ (Figure 4). The dendogram had two major groups, namely group 1 contained Situjuah, Ramindo 1, and Matur, whilefor group 2 is only Padang 3. Both of these groups are divided on the point of similarity coefficient of 0.29 or $29 \%$. Then the group 1 is divided at the point coefficient of approximately $42.25 \%$, there is a population group Situjuah 1a and Ramindo 1 and for group $1 b$ is population Matur. Population Situjuah and Ramindo 1 separated at similarity range of values abour $51.5 \%$. Coefficient $100 \%$ on the value contained in the fourth of the population with a sense of the value of having close coefficient diversity. For Situjuah population, Ramindo 1, and Padang 3 that the coefficient value of $100 \%$ is divided into three groups while the Maturpopulation is divided into 2 groups.

The similarity coefficient value based on the combination of qualitative and quantitative characters shows that the four populations of ramie plants that have been characterized are divided into two major groups, namely group 1 (Situjuah, Ramindo, and Matur) and group 2 (Padang 3). This happens because of the similarity in the character of each population. The relationship pattern of the ramie plant population has a similarity with the similarity coefficient of $17 \%-75 \%$ (Figure 5). In Situjuah and Matur accessions and Ramindo 1 clones are included in group 1 which is divided into groups $1 \mathrm{a}$ and $1 \mathrm{~b}$, where $1 \mathrm{~b}$ is only Matur accession whereas la consists of Situjuah accession and Ramindo 1 clone. The group is in a coefficient of about $28 \%$ or 0.28 . Then in group 1a again split into 2 subgroups, namely groups $1 \mathrm{a} 1$ and group $1 \mathrm{a} 2$ at a coefficient of around $33.5 \%$ or 0.335 . Group 1a1 consisted of accession Situjuah 1 to Situjuah 10 while in group 1a2 consisted of Ramindo 11 clones to Ramindo 1 10. In Ramindo 15 clones with Ramindo 18 and Padang 
31 with Padang 35 had close kinship relations with coefficient values around $70 \%$. Ramie plants in one variant have the same morphological character, so the kinship is relatively close. In other words, the diversity of morphological characters in the same variant is quite low. This event occurred only on the access of MTR-3 with MTR-5 which has a 75\% similarity relationship.

Relationships between populations classified as close are found in the same location. According to Alemu et al. (2018) the similarity coefficient values showed similarities of cultivars in a crop population, where the higher the similarity coefficient values between individuals showed that the genetic kinship of the cultivar was getting closer. The similarity of characters is also thought to be closely related to the location of growth that is relatively the same geographically. While hemp plants in the same similarity coefficient value but come from different regions and have different morphological characters, the two ramie plants have a kinship relationship that is farther than those that grow in the same environment.

From the results of the morphological characters observed and from the dendogram image it is known that the more morphological characters are the same, the closer the kinship relationship or the fewer the morphological characters are the same, the more distant kinship is. In accordance with the statement from Szenejko and Rogalski (2015) that if the higher the coefficient value, the higher the level of similarity, or if the lower the coefficient value, the lower the level of similarity.

\subsection{Molecular Characterization of Ramie}

Primary primers who were able to show the closeness of the relationship between accession and ramie plant clones were indicated by the presence of different banding patterns at the same distance using five primers in PCR amplification. The results of primary amplification using the RAPD technique for four populations of ramie plants in detail are shown in Table 3.

Based on Table 3, the number of ribbon patterns produced from PCR amplification is 74 bands. From the number of bands it is known that 68 of them are polymorphic bands. While for the number of monomorphic bands as many as 6 bands. Each one of the primers used is able to get 11 to 20 DNA fragments so that using the RAPD technique is able to select the level of polymorphism in a fast period of time. Products from PCR amplification using five primers give a high polymorphism value, indicated by a percentage value of $90 \%$. According to Garg et al. (2015) the tested plants have a fairly high diversity so as to provide a high value of polymorphism.

DNA bands that appear on DNA samples analyzed are closely related to or not the primary primers of RAPD used to amplify DNA accession of ramie plants by comparison. The number of bands produced by each primer depends on the distribution of homologous sites with primary sequences in microsatellite regions.

\subsection{Similarity Analysis}

The results of the analysis of the similarities of the four ramie plant populations resulting from PCR amplification using the NTSYS version 2.02 software program are presented in the form of a dendogram (Figure 6).

From Figure 6, it is known that there are two large groups between four populations of ramie plants with a coefficient of similarity equal to $25 \%$ to $51 \%$. Large groups have kinship relationships between individuals in very remote populations or very small genetic similarities at the coefficient point of $25 \%$. Group 1 is access to Situjuah and Padang 3 clones, where the coefficient points are at $51 \%$. From the coefficient point, it is known that among the population of accession in Situjuah and Padang 3 clones has the closest kinship relationship among all. Then in the second group divided at the coefficient point $42.5 \%$ or equal to 0.425 . In this second group there are Matur accessions and Ramindo 1 clones. Close kinship relationships show low genetic diversity and vice versa if the long kinship relationship shows high genetic diversity.

\section{FIGURES AND TABLES}

Table 1. Details of Plants Accession Number Rami per District, Sub district, Coordinates, and Altitude

\begin{tabular}{|c|c|c|c|c|c|}
\hline \multicolumn{2}{|c|}{ Locations } & \multirow{2}{*}{$\begin{array}{c}\text { Accession } \\
\text { Code }\end{array}$} & \multicolumn{2}{|c|}{ Coordinate } & \multirow{2}{*}{$\begin{array}{c}\text { Altitude } \\
\text { (masl) }\end{array}$} \\
\hline Dis tricts & Sub district & & South Latitude & East Longitude & \\
\hline Agam & Matur & MTR 1 & $0^{\circ} 15^{\prime} 28 "$ & $100^{\circ} 15^{\prime} 46^{\prime \prime}$ & 1053 \\
\hline Agam & Matur & MTR 2 & $0^{\circ} 15^{\prime} 28 "$ & $100^{\circ} 15^{\prime} 46^{\prime \prime}$ & 1053 \\
\hline Agam & Matur & MTR 3 & $0^{\circ} 15^{\prime} 28 "$ & $100^{\circ} 15^{\prime} 46 "$ & 1053 \\
\hline Agam & Matur & MTR 4 & $0^{\circ} 15^{\prime} 28 "$ & $100^{\circ} 15^{\prime} 46^{\prime \prime}$ & 1053 \\
\hline Agam & Matur & MTR 5 & $0^{\circ} 15^{\prime} 28 "$ & $100^{\circ} 15^{\prime} 46^{\prime \prime}$ & 1053 \\
\hline Agam & Matur & MTR 6 & $0^{\circ} 15^{\prime} 30 "$ & $100^{\circ} 15^{\prime} 45^{\prime \prime}$ & 1058 \\
\hline Agam & Matur & MTR 7 & $0^{\circ} 15^{\prime} 30 "$ & $100^{\circ} 15^{\prime} 45^{\prime \prime}$ & 1058 \\
\hline
\end{tabular}




\begin{tabular}{|c|c|c|c|c|c|c|}
\hline Agam & Matur & & MTR 8 & $0^{\circ} 15^{\prime} 30 "$ & $100^{\circ} 15^{\prime} 45^{\prime \prime}$ & 1058 \\
\hline Agam & Matur & & MTR 9 & $0^{\circ} 15^{\prime} 30 "$ & $100^{\circ} 15^{\prime} 45^{\prime \prime}$ & 1058 \\
\hline Agam & Matur & & MTR 10 & $0^{\circ} 15^{\prime} 30 "$ & $100^{\circ} 15^{\prime} 45^{\prime \prime}$ & 1058 \\
\hline 50 Kota & Situjuah Limo & Nagari & STJ 1 & $0^{\circ} 18^{\prime} 19 "$ & $100^{\circ} 35^{\prime} 32 "$ & 588 \\
\hline 50 Kota & Situjuah Limo & Nagari & STJ 2 & $0^{\circ} 18^{\prime} 19 "$ & $100^{\circ} 35^{\prime} 32 "$ & 588 \\
\hline 50 Kota & Situjuah Limo & Nagari & STJ 3 & $0^{\circ} 18^{\prime} 19 "$ & $100^{\circ} 35^{\prime} 32 "$ & 588 \\
\hline 50 Kota & Situjuah Limo & Nagari & STJ 4 & $0^{\circ} 18^{\prime} 19 "$ & $100^{\circ} 35^{\prime} 32 "$ & 588 \\
\hline 50 Kota & Situjuah Limo & Nagari & STJ 5 & $0^{\circ} 18^{\prime} 19 "$ & $100^{\circ} 35^{\prime} 32 "$ & 588 \\
\hline 50 Kota & Situjuah Limo & Nagari & STJ 6 & $0^{\circ} 18^{\prime} 19 "$ & $100^{\circ} 35^{\prime} 30^{\prime \prime}$ & 608 \\
\hline 50 Kota & Situjuah Limo & Nagari & STJ 7 & $0^{\circ} 18^{\prime} 19 "$ & $100^{\circ} 35^{\prime} 30^{\prime \prime}$ & 608 \\
\hline 50 Kota & Situjuah Limo & Nagari & STJ 8 & $0^{\circ} 18^{\prime} 19 "$ & $100^{\circ} 35^{\prime} 30^{\prime \prime}$ & 608 \\
\hline 50 Kota & Situjuah Limo & Nagari & STJ 9 & $0^{\circ} 18^{\prime} 19 "$ & $100^{\circ} 35^{\prime} 30^{\prime \prime}$ & 608 \\
\hline 50 Kota & Situjuah Limo & Nagari & STJ 10 & $0^{\circ} 18^{\prime} 19 "$ & $100^{\circ} 35^{\prime} 30^{\prime \prime}$ & 608 \\
\hline
\end{tabular}
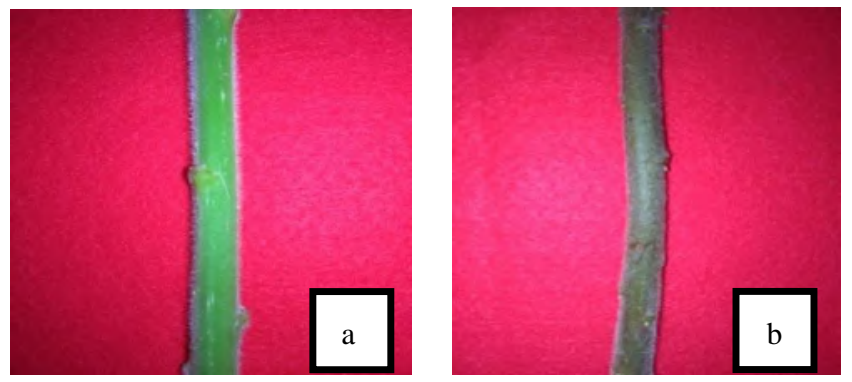

Fig.1. Color Stem Ramie, a) Color Young Stem, b) Color Old Stem
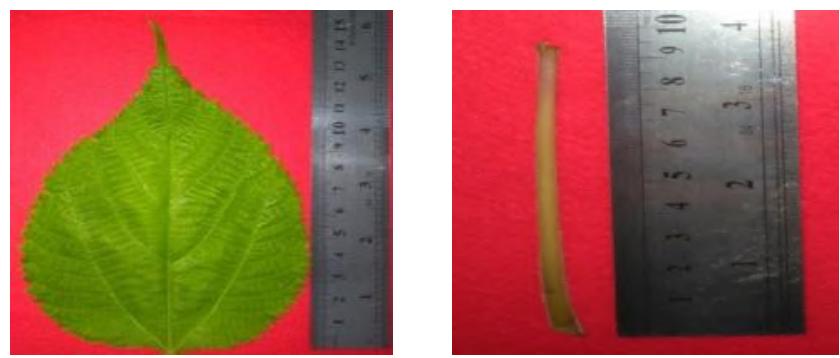

Fig.2: Measurement of Leaf Length and Leaf Petiole Length
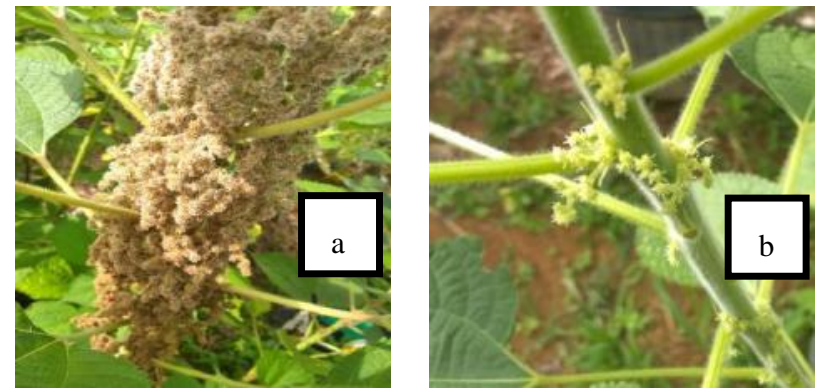

Fig.3. Number of Flowers on Ramie, a) MoreFlower, b) Less Flowering

Table 2. Phenotypic Variability based Quantitative and Qualitative Characters Ramie Plants

\begin{tabular}{cccccc}
\hline No. & Character & S2 & St Dev & 2 X St Dev & Criteria \\
\hline 1 & Leaf outline & 0 & 0 & 0 & Narrow \\
2 & Leaf margins & 0 & 0 & 0 & Narrow \\
3 & Leaf apex & 0 & 0 & 0 & Narrow \\
4 & Leaf Base & 0 & 0 & 0 & Narrow
\end{tabular}


5

6

7

8

9

10

11

12

13

14

15

16

17

18

19

20

21

22

23

24

25

26

27

28

29
Color of leaf petiole

Color of the upper surface of leaf

Color of the under surface of leaf

Color of shoot leaf

Leaf measure type

Color of midrib

Shape of midrib

Leaf hairs

Type of flowering

Color of female flower

Color of male flower

Gender of flowers

Stem surface

Color young stem

Color old stem

Plant height

Stem diameter

Leaf length

Leaf width

Leaf petiole length

Number of tillers per plant

Harvest time

Plant fresh weight

Stem fresh weight

Crude fiber weight
1.68

0.16

0

0.59

0.18

0

0

0.21

0.25

1.25

0.75

0.18

0.25

0

0

647.00

3.36

6.39

4.34

2.09

73.74

14.75

32751.2

10127.08

143.52
1.29

0.4

0

0.76

0.43

0

0

0.46

0.5

1.11

0.86

0.43

0.5

0

0

25.43

1.83

2.52

2.08

1.44

8.58

3.84

180.97

100.63

11.98
2,59

0.8

0

1.53

0.86

0

0

0.93

1

2.23

1.73

0.86

1

0

0

50.87

3.67

5,05

4.16

2.89

17.17

7.68

361.94

201.26

23.96
Narrow

Narrow

Narrow

Narrow

Narrow

Narrow

Narrow

Narrow

Narrow

Narrow

Narrow

Narrow

Narrow

Narrow

Narrow

Large

Narrow

Large

Large

Narrow

Large

Large

Large

Large

Large

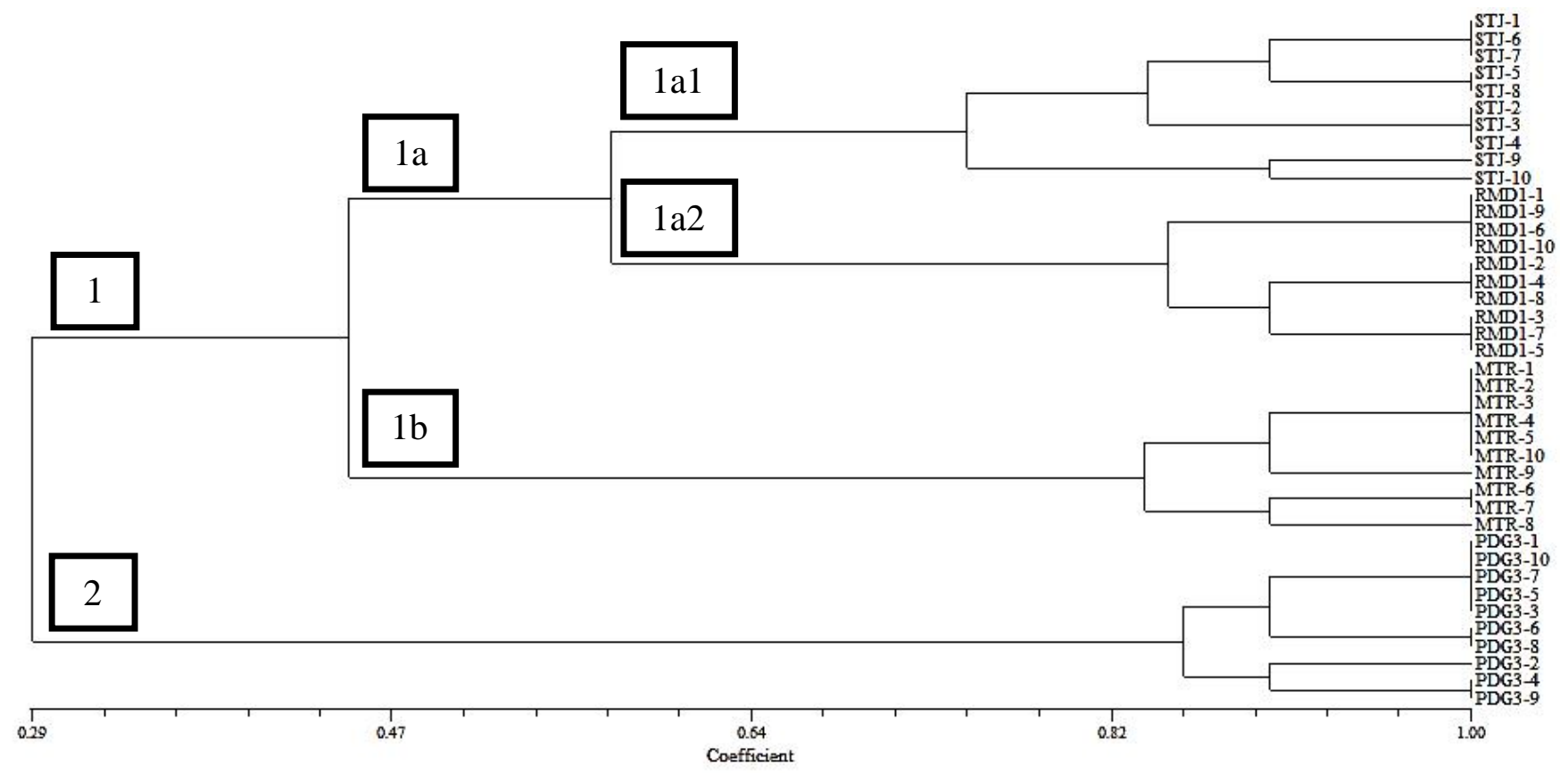

Fig.4: Dendogram with 40 Sample Ramie based on Qualitative Characters 


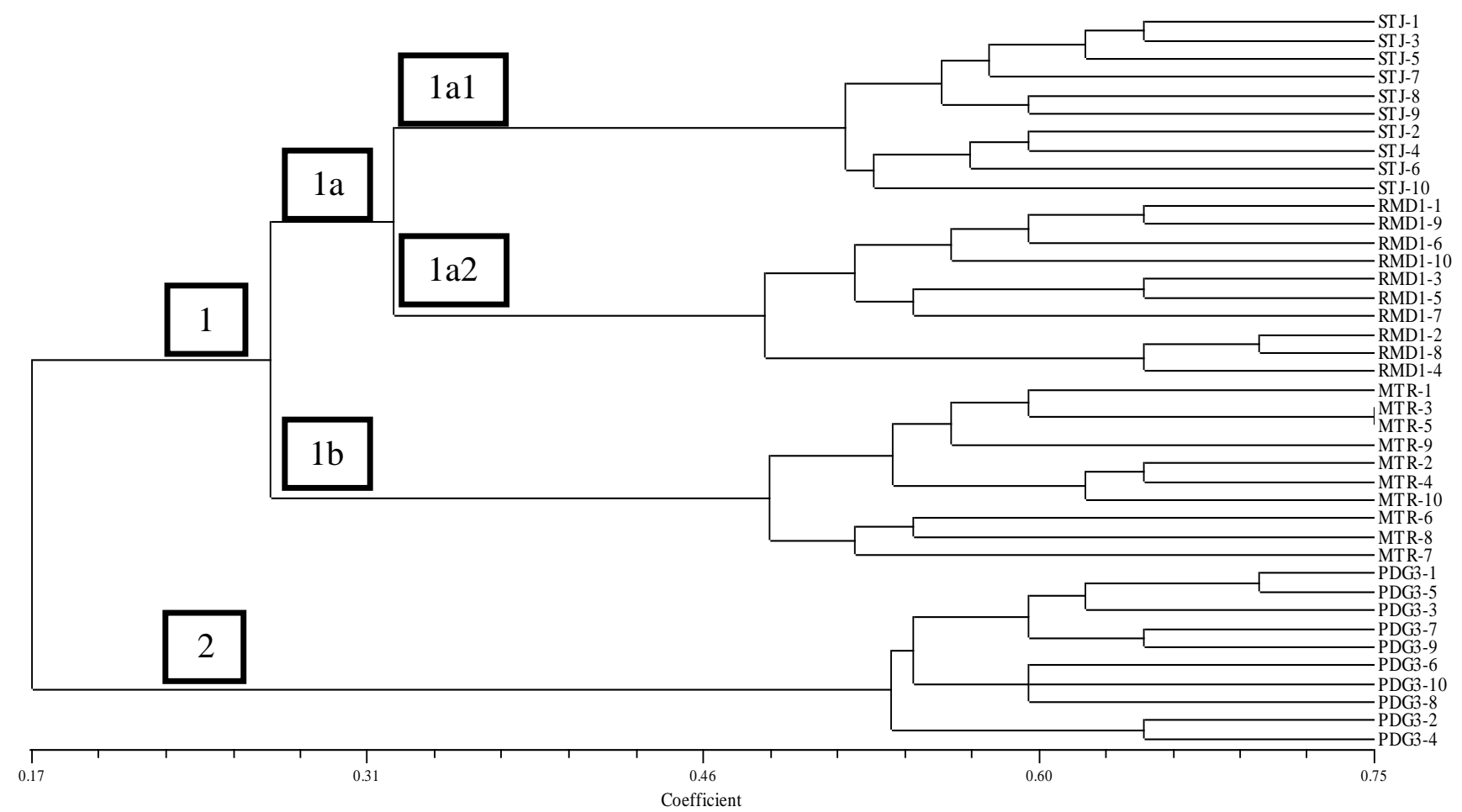

Fig.5: Dendogram with 40 Sample Ramie based on Quantitative and Qualitative Characters

Table 3. The primers used in RAPD and band profiles generated from four populations ramies

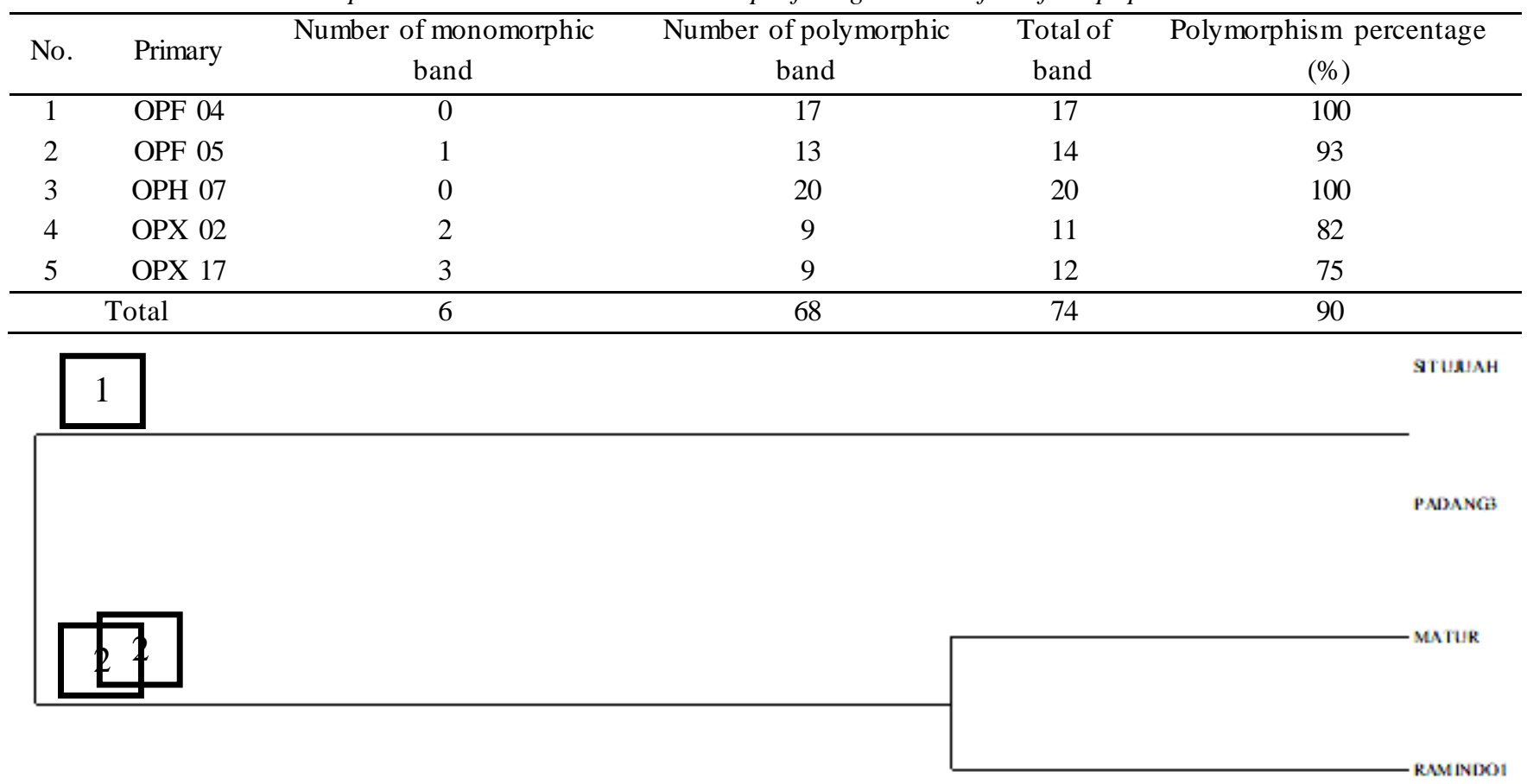

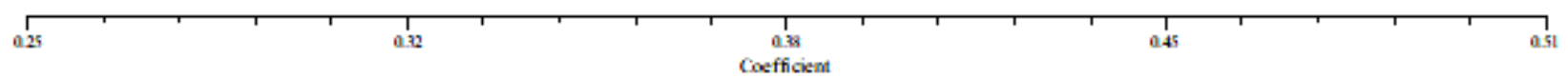

Fig.6: Dendogram with Four Populations Ramie's based on Molecular Characterization 


\section{CONCLUSION}

The spread of the ramies are in two districts of Agam and 50 Kota. All qualitative cahracters and two quantitative characters (stem diameter and leaf petiole length) were observed in the ramies showed no variety. While eight out of ten quantitative characters who observed that there are variations.

Ramie's are divided into two groups based on morphological characters were observed at the level of the lowest coefficient of $17 \%$. Group 1 (Situjuah, Ramindo, and Matur) with the level of similarity 28\%, for group 2 (Padang 3) the level of similarity 52.5\%. This grouping occurred because of the similarity in the character of each kind.

Number of banding pattern resulting from PCR amplification is as many as 74 bands (68 a polymorphic band while the rest is the number of monomorphic band). Each primer used could get 11 to 20 DNA fragments so that using RAPD technique is able to select the degree of polymorphism within a short time.

\section{REFERENCES}

[1] Aiguo, Z. (2018, March 20). Ramie (Boehmeria nivea) production and its diverse uses in China.Retrieved fromhttp://www.fibrafp7.net/ Portals / 0 / 2nd / 27/2Aiguo.pdf

[2] Alemu, B, D. Lule, K. Tesfaye, and T. Haileselassie. (2018). Interrelationship of quantitative traits and genetic variability of Desi type chickpea genotypes as revealed by agro-morphology and inter simple sequence repeat markers. African Journal of Biotechnology 17 (21), pp. 685-693.

[3] Amien, S, VS Nalang, and L. Agustina. (2014). The fifth national report to theconvention on biological diversity. Jakarta: Ministry of Environment and Forestry, pp. 83.

[4] Andrew, R. L, IR Wallis, CE Harwood, and WJ Foley. (2010). Genetic and environmental contributions to variation and population divergence in a broad-spectrum foliar defense of Eucalyptus tricarpa. Annals of Botany 105, pp. 707-717.

[5] Angelini, L. G, and S. Tavarini. (2013). Ramie (Boehmeria nivea (L.) Gaud.) As a potential new fiber crop for the Mediterranean region: growth, crop yield and fiber quality in a long-term field experiment in Central Italy. Industrial Crops and Products 51, pp. 138-144.

[6] Bene, C. D, S. Tavarini, M. Mazzoncini, and LG Angelini. (2011). Changes in soil chemical parameters and organic matter balance after 13 years of ramie [Boehmeria nivea (L.) Gaud.] Cultivation in the Mediterranean Region. European Journal of Agronomy 35, pp. 154-163.

[7] Directorate General of Estate Crops. (2017). Tree crop of real statistic of Indonesia from 2015 to 2017. Jakarta: Ministry of Agriculture, pp. 22.
[8] Garg, M, ET Tamboli, M. Singh, K. Chester, MZ Abdin, Chandna R., and S. Ahmad. (2015). RAPD-based assessment of genetic diversity of Adhatoda vasica leaves from different sub-continents of India. Indian Journal of Pharmaceutical Education and Research 49 (3), pp. 231239.

[9] Govindaraj, M, M. Vetriventhan, and M. Srinivasan. (2015). Importance of genetic diversity of crop plants and assessment in its recent advance: an overview of its analytical perspectives. Genetics Research International 2015, pp. 14.

[10] Huang, C. J, G. Wei, YC Jie, JJ Xu, SY Zhao, LC Wang, and SA Anjum. (2015). Responses of gas exchange, chlorophyll synthesis and ROS-scavenging systems to salinity stress in two ramie (Boehmeria nivea L.) cultivars. Photosynthetica 53 (3), pp. 455-463.

[11] Hwang, MS (2010). Morphological differences between ramie and ramie: Reviews These characteristics how different procedures developed in bast fiber producing industry. Lincoln: Textile Society of America Symposium Proceedings, pp. 11.

[12] Jose, S, S. Rajna, and P. Ghosh. (2017). Ramie fiber processing and value addition. Asian Journal of Textile 7 (1), pp. 1-9.

[13] Liu, L. J, ZQ Meng, B. Wang, XX Wang, JY Yang, and DX Peng. (2009). Genetic diversity among wild resources of the genus Boehmeria Jacq. from West China determined using inter-simple sequence repeat and rapid amplification of polymorphic DNA markers. Plant Production Science 12 (1), pp. 88-96.

[14] Liu, T, S. Tang, S. Zhu, and Q. Tang. (2014). QTL mapping for fiber yield-related traits by constructing the first genetic linkage map in ramie (Boehmeria nivea L. Gaud). Molecular Breeding 34 (3), pp. 883-892.

[15] Liu, T, S. Zhu, Q. Tang, and S. Tang. (2015). Genomewide transcriptomic profiling of ramie (Boehmeria nivea Gaud L.) in response to cadmium stress. Gene 558, pp. 131-137.

[16] Mayerni, R, A. Sharif, and R. Sartika. (2018). Characterization of agronomical traits and quality from three clones of the ramie plant (Boehmeria nivea (L.) Gaud.) In ultisol Limau Manis. Indonesian Journal of Crop Science 1 (1), pp. 1-8.

[17] Mitra, S, S. Saha, B. Guha, K. Chakrabarti, P. Satya, AK Sharma, SP Gawande, M. Kumar, and M. Saha. (2013). Ramie: the strongest bast fiber of nature. 8th ed Technical Bulletin, pp.38.

[18] Mulder, H. A, P. Gienapp, and ME Visser. (2016). Genetic variation in variability: phenotypic variability of fledgingweight and its evolution in a songbird population. Evolution 70 (19), pp. 13.

[19] Munawar, S. S, K. Umemura, and S. Kawai. 2007. The characterization of the morphological, physical, and mechanical properties of seven nonwood plant fiber bundles. Journal of Wood Science 53, pp. 108-113. 
[20] Sarkar, D, MK Sinha, A. Kundu, CS Kar, A. Saha, LL Kharbikar, and BS Mahapatra. (2010). Why is the strongest yet stiffest ramie bast fiber?. Current Science 98 (12), pp. 1570-1572.

[21] Satya, P, S. Mitra, DP Ray, BS Mahapatra, M. Karan, S. Jana, and AK Sharma. (2013). Rapid and inexpensive $\mathrm{NaOH}$ based direct PCR for the amplification of nuclear and organelle DNA from ramie (Boehmeria nivea), a bast fiber crop containing complex polysaccharides. Industrial Crops and Products 50, pp. 532-536.

[22] Sharma, A. K, SP Gawande, PG Karmakar, and S. Satpathy. (2014). Genetic resource management o ramie (Boehmeria sp.): A bast fiber crop of North Eastern India. Vegetos 27 (2), pp. 279-286.

[23] Sury anah, S, A. Rochana, I. Susilawati, and NP Indiriani. (2017). Ramie (Boehmeria nivea) plant nutrient feed forage quality as cutting at various ages. Animal Production 19 (2), pp. 111-117.

[24] Szenejko, M, and M. Rogalski. (2015). Characterization of morphological traits and RAPD polymorphism in selected forms of Kentucky bluegrass (Poa pratensis L.). Biodiversity Research and Conservation 37, pp. 1-10.

[25] Verdaguer, D, MAK Jansen, L. Llorens, LO Morales, and S. Neugart. (2017). UV-A radiation effects on higher plants: exploring the known unknown. Plant Science 255, pp. 72-81.

[26] Yang, B, M. Zhou, WS Shu, CY Lan, ZH Ye, RL Qiu, YC Jie, Cui GX, and MH Wong. (2010). Constitutional tolerance to heavy metals of a fiber crop, ramie (Boehmeria nivea), and its potential usage. Environmental Pollution 158, pp. 551-558. 